\title{
Management of nursing care in HIV/AIDS from a palliative and hospital perspective
}

\author{
Gerência do cuidado de enfermagem em HIV/aids na perspectiva paliativa e hospitalar \\ Gestión del cuidado de enfermería en VIH/SIDA en la perspectiva paliativa y hospitalaria
}

Karen Gisela Moraes Zepeda '
ORCID: 0000-0001-8390-3579
Marcelle Miranda da Silva'
ORCID: 0000-0003-4872-7252

Débora Cristina Leitão dos Santos' ORCID: 0000-0003-1475-7541

Rafael Barroso Gaspar' ORCID: 0000-0002-1042-3096

Liana Amorim Corrêa Trotte'

ORCID: 0000-0002-6579-7108

'Universidade Federal do Rio de Janeiro. Rio de Janeiro, Rio de Janeiro, Brazil.

How to cite this article: Zepeda KGM, Silva MM, Santos DCL, Gaspar RB, Trotte LAC. Management of nursing care in HIV/AIDS from a palliative and hospital perspective. Rev Bras Enferm. 2019;72(5):1234-50. doi: http://dx.doi.org/10.1590/0034-7167-2017-0431

Corresponding Author:

Marcelle Miranda da Silva

E-mail: marcellemsufrj@gmail.com

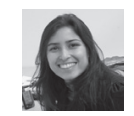

Submission: 06-02-2017

Approval: 06-08-2018

\section{ABSTRACT}

Objectives: To understand the meaning attributed by the nurse to the management of nursing care to the person hospitalized due to clinical complications caused by AIDS; to analyze actions related to palliative care; and to construct a theoretical matrix regarding the management of nursing care. Method: Qualitative, exploratory research, guided by the Grounded Theory. Seven nurses and ten nursing technicians were interviewed between May and September 2015, in a university hospital, located in Rio de Janeiro State, Brazil. Results: Five categories that covered the profile of the hospitalized person, palliative care, intervening conditions for care management, the need for professional qualification, and other aspects to better organize and manage care, including conflict management arose. Final considerations: The theoretical matrix values the quality of life, the need to understand the flow of care to avoid readmissions and not adherence to medications, requiring new research in the area, such as implementation. Descriptors: Nursing; HIV; Acquired Immunodeficiency Syndrome; Management; Palliative Care.

\section{RESUMO}

Objetivos: Compreender o significado atribuído pelo enfermeiro à gerência do cuidado de enfermagem à pessoa hospitalizada por complicações clínicas da aids; analisar as ações que remetem aos cuidados paliativos; e construir uma matriz teórica referente à gerência do cuidado de enfermagem. Método: Pesquisa qualitativa, exploratória, guiada pela Grounded Theory. Sete enfermeiros e dez técnicos de enfermagem foram entrevistados entre maio e setembro de 2015, num hospital universitário, localizado no Rio de Janeiro, Brasil. Resultados: Foram geradas cinco categorias que abarcaram o perfil da pessoa hospitalizada, os cuidados paliativos, as condições intervenientes à gerência do cuidado, a necessidade de qualificação profissional, e outros aspectos para melhor organizar e administrar o cuidado, incluindo a administração de conflitos. Considerações finais: A matriz teórica valoriza a qualidade de vida, a necessidade de entendimento do fluxo de atendimento para evitar reinternações e não aderência às medicações, requerendo novas pesquisas na área, como as de implementação.

Descritores: Enfermagem; HIV; Síndrome de Imunodeficiência Adquirida; Gerência; Cuidados Paliativos.

\section{RESUMEN}

Objetivos: Comprender el significado atribuido por el enfermero al manejo del cuidado de enfermería a la persona hospitalizada por complicaciones clínicas del sida; analizar las acciones que remiten a los cuidados paliativos; y construir una matriz teórica referente al manejo del cuidado de enfermería. Método: Investigación cualitativa, exploratoria, guiada por Grounded Theory. Siete enfermeros y diez técnicos de enfermería fueron entrevistados entre mayo y septiembre de 2015 , en un hospital universitario, Río de Janeiro, Brasil. Resultados: Se han generado cinco categorías que abarcar el perfil de la persona hospitalizada, los cuidados paliativos, las condiciones intervinientes para la gestión del cuidado, la necesidad de cualificación profesional, y aspectos para organizar y administrar el cuidado. Consideraciones finales: La matriz teórica valoriza la calidad de vida, la necesidad de entender el flujo de atención para evitar reinternaciones y no adherencia a las medicinas, requiriendo nuevas investigaciones en el área, como las de implementación.

Descriptores: Enfermería; VIH; Síndrome de Inmunodeficiencia Adquirida; Gestión; Cuidados Paliativos. 


\section{INTRODUCTION}

People living with HIV/AIDS (PLWHA) are more vulnerable to the development of serious infections, which, over the course of the disease, may require hospital admission and increase morbidity and mortality rates, especially in cases where there is microbial resistance to antibiotics ${ }^{(1)}$.

Although Highly Active Antiretroviral Therapy (HAART) decreases the likelihood of PLWHA disease and death, nonadherence to treatment is an alarming problem that contributes to the emergence of clinical complications of AIDS, such as opportunistic diseases. Consequently, this disease causes prolonged hospitalizations that compromise people's quality of life and expose them even more to nosocomial infections ${ }^{(1-5)}$.

Results from a study carried out at the Instituto de Infectologia Emílio Ribas (freely translated as Institute of Infectology Emílio Ribas) in São Paulo city show that of the 109 patients with HIV/AIDS hospitalized in the Intensive Care Unit between January 2006 and December $2012,89 \%$ had reports of opportunistic diseases (predominantly tuberculosis), 70\% had CD4 lower than 100 cels/mm3 and only $19 \%$ adhered to the treatment. The overall mortality rate was $88 \%{ }^{(4)}$.

Given the peculiarity of AIDS as a chronic, progressive, incurable condition that threatens the continuity of life, PLWHA palliative care is appropriate at any stage of infection, not only at the end of life ${ }^{(6)}$. However, in practice, palliative care, mainly due to the difficulty in achieving the prognosis and knowledge deficit of the health team on the subject, are implemented late, mainly in cases of patients with a high severity and mortality profile, with short survival, interfering in the level of use of the benefit of their actions for a good death and therapeutic proportions ${ }^{(4)}$.

The implementation of palliative care for PLWHA is permeated with complexities inherent in their experiences, often being affected by multiple comorbidities and submitted to polypharmacy, which results in an important functional decline ${ }^{(7-8)}$. In the final phase of life, the implementation of palliative care can prevent therapeutic futility and contribute to beneficence, among other principles of bioethics; since the planning of their actions reflects a significant reduction in the use of blood products, antibiotics, prophylaxis against opportunistic diseases and HAART for patients already diagnosed at this stage, as well as the non-use of measures for prolonging life with artificial supports ${ }^{(4)}$.

However, palliative care may contribute to the appropriate symptomatic approach, including the side effects of HAART, and attention to psychosocial and emotional aspects in the face of a person's depression, anxiety, fear, and social vulnerability. Thus, the focus of interdisciplinary actions should include support to the family of the sick patient around the afflictions, based on discussions about present and future, and the valorization of quality of life ${ }^{(9-10)}$.

Within the multiprofessional team, especially in the hospital setting, the nurse is responsible for the management of care, present 24 hours, active in direct and continuous care, and plays a fundamental role in the implementation of palliative care for patients with HIV/ AIDS $^{(11)}$. It should be emphasized that care management is a dynamic activity and is based on the triad that values the health team, the institution and the patient/family, where the nurse is in the center, encouraging and favoring interaction between all parties for the construction of symbols and meanings about the lived experience ${ }^{(12)}$.

\section{OBJECTIVE}

To understand the meaning attributed by the nurse to the management of nursing care to the person hospitalized due to clinical complications caused by AIDS; to analyze the actions of nurses who refer to palliative care; and to construct a theoretical matrix regarding the management of nursing care in the context of palliative care to the person hospitalized due to clinical complications caused by AIDS.

\section{METHODS}

\section{Ethical aspects}

The study was conducted based on the recommendations of Resolution 466/2012 of the National Health Council (Conselho Nacional de Saúde) of the Ministry of Health, which guides human research. The project was approved by the Research Ethics Committees of the proposing institution and the participating institution. During the study participants were given the opportunity to withdraw their consent without any loss. In order to maintain their anonymity, alphanumeric codes were used to identify their statements, using the letter " $T$ "for the nursing technician and the letter " $\mathrm{N}$ "for nurses, followed by an Arabic numeral corresponding to the order of accomplishment of interviews. All participants signed the Informed Consent Form.

\section{Type of study and methodological framework}

This is an exploratory, qualitative study that used the Grounded Theory, following the full conceptual description approach. By means of this method, it is sought to base concepts on data extracted from the empirical realities, involving subjects in constant interaction ${ }^{(12)}$.

The Grounded Theory aims to discover a conceptual matrix that explains the phenomenon to be investigated and enables the researcher to develop and relate concepts.

\section{Study setting}

The data were collected between May and September of 2015 in the clinical ward of a federal university hospital, located in the city of Rio de Janeiro, Brazil, which has a tradition in caring for clients with HIV/AIDS.

The hospital is intended for the clinical ward to receive patients with HIV in situations that require hospitalization, either due to clinical complications in the face of infectious conditions, for example, or for any other comorbidities. It has 14 beds, one of which is equipped with a cardiac monitor and near a crash cart, in order to provide support for some patients who may have their clinical condition aggravated and need to be monitored until they are transferred to the Intensive Care Unit, if so conducted.

The nursing team that works in this ward is composed of a nurse and a nursing technicians day laborers, who work from 7:00 a.m. to 4:00 p.m., from Monday to Friday, and a nurse and four nursing technicians on call. The on-call staff fulfills the workload of 30 hours a week, thus, there are three day shifts and three different night shifts.

\section{Collection and organization of data}

The technique of data collection used was the semi-structured interview. Two sample groups were studied, totaling 17 participants, as shown in Chart 1. 
Chart 1 - Presentation of sample groups

\begin{tabular}{|c|c|c|c|c|}
\hline Groups & Participants & Inclusion criteria & Exclusion eriteria & Question \\
\hline $\begin{array}{c}1^{\text {st }} \text { Sample } \\
\text { Group }\end{array}$ & $\begin{array}{c}\text { Seven (07) nurses, being one day } \\
\text { laborer, three day on-duty nurses } \\
\text { and three night on-duty nurses. }\end{array}$ & $\begin{array}{c}\text { Have employment } \\
\text { relationship with } \\
\text { the institution and } \\
\text { minimum experi- } \\
\text { ence of two years in } \\
\text { the ward. }\end{array}$ & $\begin{array}{c}\text { Nurses and nursing } \\
\text { technicians away } \\
\text { from work for any } \\
\text { reason during the } \\
\text { period of data col- } \\
\text { lection. }\end{array}$ & $\begin{array}{c}\text { What does it mean for you to manage the care } \\
\text { of the person hospitalized due to clinical com- } \\
\text { plications caused by AIDS from the perspective } \\
\text { of palliative care? }\end{array}$ \\
\cline { 1 - 2 } $\begin{array}{c}2^{\text {nd }} \text { Sample } \\
\text { Group }\end{array}$ & $\begin{array}{c}\text { Ten (10) nursing technicians, be- } \\
\text { ing a day laborer, and the other } \\
\text { on-duty nurses with experience in } \\
\text { the two shifts. }\end{array}$ & $\begin{array}{c}\text { What does it mean for you to care for the } \\
\text { person hospitalized due to clinical complica- } \\
\text { tions caused by AIDS from the perspective of } \\
\text { palliative care? }\end{array}$ \\
\hline
\end{tabular}

The choice of participants in the first group met the requirements of the study object. And as in the Grounded Theory, data collection and analysis take place simultaneously, allowing the researcher to seek other directions by constructing hypotheses that direct approach to new groups, directing the second sample group to consider the active participation of the nursing care, being a primordial element to the adequate management of care.

It should be emphasized that the concept of theoretical sampling encompasses the possibility of the researcher searching their data in places or through the testimony of people who indicate that they have knowledge about the reality investigated, and facilitates the theoretical saturation, indicating the moment of interruption of data collection, according to the qualitative approach.

The interviews were conducted individually, recorded with an electronic audio device, averaging 30 minutes each, and were re-submitted to the participants for validation.

\section{Data analysis}

Data analysis was structured by open, axial and selective coding processes. The raw data were transcribed line by line, giving rise to the preliminary codes. The grouping of these generated the conceptual codes that, in turn, formed categories and/or subcategories. Using the paradigmatic model, the five categories generated were interconnected to construct the theoretical matrix and reveal the central phenomenon. It is emphasized that the paradigmatic model seeks to integrate structure and process, related to actions and interactions in time, in space, with people, organizations and societies, in response to problems. Structural conditions include the causal conditions, context and intervening conditions. The process focuses on action/interaction strategies and on consequences. Strategies can be individual or collective and signify actions in the face of problems. And the consequences represent the results achieved or expectations $s^{(12)}$.

The conceptual basis for palliative care was used as a reference for interpretation of data, including its definition by the World Health Organization, in accordance with good practices in HIV and AIDS advocated by national and international entities such as the Department of Surveillance, Prevention and Control of STIs, HIV/AIDS and Viral Hepatitis, the Ministry of Health and the Associação Brasileira Interdisciplinar de Aids (freely translated as Brazilian Interdisciplinary Association of Aids - ABIA) in Brazil, as well as philanthropic entities with a strong global membership, such as the Joint United Nations Program on HIV/AIDS (UNAIDS).

\section{RESULTS}

During the analytical process, five categories were generated, as can be seen in Chart 2 .

Chart 2 - Presentation of categories and subcategories

\begin{tabular}{|c|l|}
\hline \multicolumn{1}{|c|}{ Categories } & \multicolumn{1}{c|}{ Subcategories } \\
\hline $\begin{array}{c}\text { Context } \\
\text { Tracing the profile of the hospitalized person }\end{array}$ & $\begin{array}{l}\text { - Evidencing their social conditions } \\
\text { - Highlighting their clinical profile and the reasons for their (re)hospitalization }\end{array}$ \\
\hline $\begin{array}{c}\text { Action/interaction strategies } \\
\text { Implementing actions that refer to the precepts of } \\
\text { palliative care }\end{array}$ & $\begin{array}{l}\text { - Discussing palliative care } \\
\text { - Preparing discharge and emphasizing the regular use of HAART and other medicines for qual- } \\
\text { ity of life } \\
\text { - Taking care of the family member } \\
\text { - Articulating with other members of the health team aiming at a comprehensive care } \\
\text { - Seeking to meet the patient's needs during hospitalization promoting physical and psychoso- } \\
\text { cial comfort }\end{array}$ \\
\hline $\begin{array}{c}\text { Intermediary conditions } \\
\text { Recognizing the factors related to the environment, } \\
\text { working conditions and ethical aspects that may } \\
\text { interfere in the management of nursing care }\end{array}$ & $\begin{array}{l}\text { - Concerning the environment and working conditions } \\
\text { - Finding ethical dilemmas }\end{array}$ \\
\hline $\begin{array}{c}\text { Consequence } \\
\text { Understanding the need for investment in pro- } \\
\text { fessional qualification }\end{array}$ & \\
\hline $\begin{array}{c}\text { Causal condition } \\
\text { Studying situations to better organize and man- } \\
\text { age nursing care }\end{array}$ & $\begin{array}{l}\text { - Managing time and possible conflicts } \\
\text { - Organizing the duties of the nursing team }\end{array}$ \\
\hline
\end{tabular}


The first category "Tracing the profile of the hospitalized person", and its subcategories, addresses the profile of the person hospitalized with HIV/AIDS, highlighting their social conditions and clinical profile, as well as the reasons for (re)hospitalization that direct the therapeutics.

The subcategory "Evidencing their social conditions" mainly emphasizes support networks such as family and living conditions, demonstrating the concern of nurses to identify whether the situation is favorable or not to the continuity of home care at the time of hospital discharge, especially by the report of constant readmissions.

There are sociocultural issues that we have to realize. We have to know who this patient is, if he is a homeless person, if he has a family structure [...]. (N1)

The subcategory"Highlighting its clinical profile and the reasons for its (re)hospitalization" indicates the most frequent clinical complications due to HIV, and some examples of the reasons are highlighted, such as worsening of the clinical condition due to vulnerability to infections due to the irregular use of HAART; by social demands; or for reasons unrelated to HIV.

Sometimes the patient is hospitalized with urinary or respiratory infection, whether it is pneumonia, tuberculosis, Kaposi's sarcoma, cryptococcal meningitis, being slimming and malnutrition are one of the consequences. I always try to talk, explain the situation and the importance of taking medication, maintaining hygiene, changing dressings, and giving continuity to home treatment. (N3)

The second category, "Implementing actions that refer to the precepts of palliative care", brings to the discussion list the need to implement palliative care in this context of action, from the moment it points out the indispensability of integration among the members of the health care to meet the needs of the patient, focusing on comfort and quality of life, as well as on the importance of family participation. It is important to emphasize the strengthening of the network in the institution itself, such as hospital care combined with outpatient and home care, as well as in the interinstitutional scope, to ensure continuity of treatment after discharge, coping with the disease, adaptive processes and minimizing the deleterious effects of the disease with regard to social vulnerability.

Palliative care is what we do to reduce pain. I will give an overview of what we had at the time [at the beginning of AIDS]. We knew that it was something that would give the patient much suffering, but mostly we treated him as every human being, surrounded by affection, attention, we encouraged the family member to participate in the care [...].We addressed the issue of their rights, from the conduction to guidance of where they should seek a condition to survive with the help of the government itself. And that affection of listening to his life, giving advice, guiding [...]. So that's it, we take up the cudgels for their pains. (N5)

Some patients are long bedridden, cachectic, and with pressure ulcers, and then, care is taken when the patient goes back home, to maintain conducts, and not to generate new problems, such as sepsis. They usually leave here feeling better. Many recover and return home. (N2)
In the case of the patient without family support, we seek to work in partnership with the Social Work and Psychology, trying to meet the needs so that he can leave here well, and able to take care of himself, because there is no one to take care of him. And the partnership strengthens, with each other, exchanging information for continuity of care. (N1)

The third category, "Recognizing the factors related to the environment, working conditions and ethical aspects that may interfere in the management of nursing care", is composed of the following subcategories: "Concerning the environment and working conditions" and "Realizing ethical dilemmas".

I take care of them in a normal way, like all other patients, and you have to be careful, do nothing without using the protective equipment. It's not a matter of discrimination, you just have to protect yourself and protect the patient. (T1)

When you don't have enough personnel and you have to relocate, I come across the problem of the technician who does not like to deal with this type of clientele. It is difficult to manage the care, because there are some that do not even approach the patient. There are others who exaggerate in protective equipment; they wear three gloves, three masks. (N7)

The nurse experiences several complex situations, such as professional secrecy regarding the diagnosis, as well as dealing with feelings and behaviors of rebellion on the part of the patient.

It is usually the doctor who gives the information. We signal to the patient that he has HIV, and then he asks not to tell his wife. But this is complex. We have to tell, because our obligation is also the care with the other. (N2)

Some are rebels. If you don't pay attention to the material, they take a needle and want to stick it in someone else; I have already seen someone wanting to get a syringe to contaminate someone else. (T5)

Even in the face of problems, emotional character and the creation of bonds strengthen co-responsibility and coping with the disease.

In the past, I wanted to be what I am today, because of maturity, humanization, because before I was very technical. Technique is important, but today I value the human side much more. I was afraid to take the patient's hand. (N6)

In the fourth category, "Understanding the need for investment in professional qualification", it was evidenced that because it is a reference hospital in the treatment of HIV/AIDS, the team was entitled to specialize in this subject, but lacking information on palliative care.

The change would be more in the sense of participating in refurbishing so that people work more closely, that is, respect the routine. Follow the routine to encourage people to study. So, I think that my participation, the will that I have, that I would like to participate in is thus, to periodically make a refurbishment. I would like to do this on my team [...].The Gaffrée has this tradition 
of HIV, so our workforce is qualified and the employees who are old dominate and those who are also entering, as this hospital is reference here end up learning here. So I would periodically do a refurbishment, especially on palliative care. (N4)

The fifth category, "Studying situations to better organize and manage nursing care", reflects the view of care management still in a dichotomized way with regard to the care and administrative dimensions of the work process, in addition to matching the concern with the time in which the nursing care is carried out, the management of the possible present conflicts in the day to day, that mainly concentrate in the relation with the relative/companion, and the attributions of each participant of the nursing team.

Normally, here we divide the functions into bureaucratic and assistance. Assistance functions are on the nurse on duty, and the bureaucratic with the day laborer. But I believe that when you have a partnership, you can share. (N1)

I try to solve the issues posed by both the family member and the patient in the best possible way, but if we observe that the companion doesn't cooperate, it creates a friction with the people [...].I try to give comfort and safety to the patient, I try to provide food, and what momentarily arises we try to solve [...]. But not everything I plan to do, because I have to solve other tasks, then sometimes I can't do that matter of evaluating the patient, promoting a sense of well-being in him. Sometimes I can't get there to say "hello", "I'm only going to say it at the end of the shift". (N3)

With the use of the paradigmatic model, the following central phenomenon was generated: When managing care for the person hospitalized due to clinical complications because of AIDS, the nurses, within the nursing and health team, value the quality of life, demonstrate concern to ensure the use of HAART at home to avoid readmissions and favor the return to activities daily life and apply measures to prevent and treat pressure ulcers that can lead to serious infections. They assume (un)conscious and (in)directly the precepts of palliative care to promote physical and psychosocial comfort, considering peculiarities of the disease and subjection to social vulnerability; seek to know their social conditions and support networks, as well as meet the needs of family members. Job adversities related to strong stigma, fears generated by the risk of contamination, and other social and institutional problems are driven by committed, empathic, and resilient practice.

\section{DISCUSSION}

The results of the study evoke the understanding of the relationships and interactions of the nurse in the management of nursing care to the person hospitalized due to clinical complications caused by AIDS and its interface with palliative care. Faced with the multidimensional connotation of the disease, in which daily challenges are faced, such as insecurity in its course, psychosocial factors as the main barrier to adherence to antiretroviral therapy, associated with stigma still existing in society ${ }^{(3)}$, and the possible fragility of networks of support, it is evident the need to empower the person to take care of themselves, to participate in families and to act within the scope of interdisciplinarity.
Even though the diagnosis of HIV can still be perceived as a "death sentence", it is now more likely to mean a chronic, debilitating disease that requires indefinite treatment for life ${ }^{(13)}$. The evolution of AIDS causes changes in the routine of life and, through the necessity of hospitalization, it is preponderant that the nurse knows the main affections, considering the social conditions, the clinical profile and the reasons inherent to the hospitalization of these people, in order to better plan care, combining theoretical and practical skills. Although a theoretical matrix about reality can be presented, it is evident that each care being has specificity, being important the unique, responsible and human look for the effective implementation of the implemented actions and attainment of the objectives.

Among the care needs, it is important to note that psychic disorders are frequent, especially in those who do not have a support network. In addition, coinfections, such as tuberculosis, were enumerated as reasons for hospitalization. Coinfections account for increased morbidity and mortality rates in patients with immunodeficiency, and are directly related to poverty and social inequality ${ }^{(14-15)}$.

The interviewees evidenced the social conditions of people hospitalized mostly as unhealthy and lacking a support network, highlighting the emotional and affective deficiencies, which could worsen the clinical condition, demand repeated hospitalizations, including of a social nature, and disrupt the high hospital. These problems reinforce "the role that individuals can play in solving everyday situations in times of crisis"(16), especially the family.

The social needs raised by nurses are handled jointly with the social service to facilitate the acquisition of government assistance, for example, since these opportunities are offered to these people with few formal employment opportunities ${ }^{(17)}$, in addition to the constant declines and disabilities in stage of disease installed.

Although deaths due to clinical complications because of AIDS have declined as treatment improves, HIV remains an incurable and life-limiting condition. There is an increasing number of PLWHA with multidimensional problems that include physical symptoms, psychic, spiritual suffering and social problems ${ }^{(9)}$. A shift in care focus is needed to address such needs by ensuring access to HAART, particularly in the light of the evidence that non-targeting to psycho-emotional suffering is associated with non-adherence to therapy ${ }^{(8)}$. However, although HAART has made HIV/AIDS a manageable chronic condition, it has paradoxically also separated the disease-centered curative treatment from the palliative approach focused on its specific symptoms, since in traditional PLWHA care, symptoms related to HAART experienced by patients were constantly neglected due to the focus on curative treatment ${ }^{(17)}$.

In the context of palliative care, actions to promote comfort and quality of life were emphasized, as in the physical sphere (hygiene, dressing, feeding and adapting to debilitating complications); (appropriate facilities such as comfortable beds, clean clothing, adequate toilets, adequate lighting and cooling); sociocultural (support networks, leisure and work); and psycho-spiritual, in an altruistic way, to "put himself in the shoe of the other" to jointly try to understand the suffering of the patient and the family, exercising active listening and zeal in confronting their own prejudices and fears about the fear of exposure to infection. 
Besides, in view of the need to adequately prepare discharge, it is necessary to educate patients and their families, facilitating self-management of the chronic condition ${ }^{(18)}$. In countries such as South Africa, community-based palliative care models, for example, are particularly needed to deal with the growing burden of HIV in formal health systems. This is relevant as more people living with HIV age and become increasingly susceptible to non-communicable diseases ${ }^{(19-20)}$.

There is evidence of the need to link efforts with support networks and levels of health care, such as Primary Care, in order to facilitate the implementation of care models to fully meet the needs of these people $\mathrm{e}^{(8)}$. For many, the community support needed for a death at home is not accessible ${ }^{(21)}$.

However, organizational problems and complex ethical issues hamper the development of work. Even with the use of managerial tools, the problems of capturing and using material resources impact the service in such a way as to affect the quality of the service provided to the population, as well as the administration of time and conflicts ${ }^{(21)}$. It is understood that ethical dilemmas are frequent and for which there are no ready answers, and the decisions to be made come from the analysis of each situation. Thus, an adequate diagnosis of the suffering and its causes for the adequate management of the palliative and hospital care is crucial.

Regarding the need for education, the focus to be given on palliative care is consistent with the lack of knowledge related to the topic. Citizen and professional training is still insufficient in dealing with palliative care and death. Faced with the lack of this knowledge, many health professionals, especially physicians, are afraid to deal with the subject, since they can be misinterpreted or confused as euthanasia practitioners. Thus, in addition to lack of knowledge, the reasons for therapeutic obstinacy go through ethical, legal, emotional difficulties, family concern, and institutional routines ${ }^{(22)}$.

Actions carried out for the management of nursing care range from the prediction and provision of resources, through the efforts to understand the biopsychosocial conditions of the patients, and their needs during and after hospitalization. Throughout the period of hospitalization, nursing care is focused on the specific needs of each patient, but in general, they cover care with basic human needs, including dimensions that go beyond the physical aspect and that commit themselves during the confrontation of the disease. Nurses need to be prepared to provide palliative care in the management of AIDS-related diseases and complications that can last for decades ${ }^{(2)}$.

To handle the various challenges, management tools are as important as the emotional intelligence employed by nurses. The decision-making process involves two complementary mechanisms, one of them of cognitive nature and the other of emotional and sentimental nature, strongly interconnected. Emotional intelligence plays an increasingly prominent role within a hospital, empowering a more flexible and collaborative work ${ }^{(23)}$.

Nonetheless, the social commitment of the nurse in this research permeates the impetus to care about the quality of life of the patient both during hospitalization and hospital discharge. In order to provide nursing care in a hospital setting, certain measures related to the management of care must be considered, since managing care implies the dialectical relationship between knowing how to manage and manage the care. The actions of nursing care management are expressive and instrumental, of direct and indirect care, and permeate the articulation and interface of technical, political, social, communicative, citizenship development and organizational aspects ${ }^{(24)}$.

Thus, this research presents the opportunity to verify that the nursing team uses, in its work process, tools that go beyond the objects necessary for the promotion of comfort and general patient care. There is also evidence of a constant need for learning about new knowledge and know-how that allow better results in order to provide a better quality of life for the clients served during hospitalization and for the continuity of care beyond hospital wards.

\section{Study limitations}

The setting of data collection was only one, which was insufficient to generalize the obtained results. Thus, from the propositions of the Grounded Theory, a theoretical matrix was constructed that could be understood in a given reality. Thus, it can be understood as a limitation of this study cut, since there was no exhaustion of all possibilities of construction of sample groups, as well as their replication in other realities, in order to generate abstract concepts that can be applied in a generalized way. This orientation requires additional research to construct a formal theory.

\section{Contributions to the sector of Nursing and Health}

The research results point to the need to manage nursing care in an articulated way, either within the nursing and health team, but mainly, intersectorial and at different care levels, given the empirical evidence of frequent rehospitalization due to clinical complications of AIDS, social hospitalizations associated with social vulnerability and problems in adherence to HAART. Thus, nurses must plan discharge, assembling efforts to ensure continuity of treatment, providing assistance to the person in coping with the disease and in adapting. This reality requires the realization of new research that seeks, for example, to map and analyze the flow of the patient in the use of health services, as in the case of hospital discharge and its therapeutic itinerary at the primary or secondary level of health care, so to improve the quality of small-scale care and to generate a positive impact on the evident inefficiencies of the health system.

In current practice in the context investigated, nurses play a key role in the implementation of care. The management of nursing care to the PLWHA encompassed the physical, psychic, social and spiritual dimensions, based on the ethical and resilient work of the nursing team. To know and to understand the psychosocial conditions related to PLWHA is fundamental in the configuration of therapeutic adherence, such as information and knowledge acquired by the bearer and his family, attitudes, feelings and beliefs about the disease and treatment, self-esteem and social support, in addition to the parameters classic biological. The repercussions of drug adherence fall on the highest survival, which, nevertheless, must be accompanied by social and family support, for its effective course. 


\section{FINAL CONSIDERATIONS}

Within the framework of the care paradigm, the adequate management of nursing care seeks to facilitate the development of fruitful actions to meet the needs of PLWHA and their families in the various spheres that permeate the hospital and palliative perspective. Thus, the need to understand the patient and his family in the aspects that surpassed the clinical complications of AIDS was evidenced, aiming to contribute to the control of the condition that demanded the hospitalization, and for continuity of the follow-up after the hospital discharge, being necessary to know the Network of Health Care of these people and their components, as in the case of specialized care at the outpatient level in the institution itself, as well as Primary Care services.

The construction of the theoretical matrix, in spite of the limitation of having emerged from a particular context, through the elements of the paradigmatic model, brings together information that can help nurses to signify their practices, seeking to align theoretical concepts related to the management of nursing care. Thus, the importance of teamwork and networking is emphasized; the enhancement of quality of life; the reduction of social vulnerability; the family approach; and concern about the regular use of HAART to prevent complications and readmissions. Such aspects may be accompanied by adversities related to deficiencies in infrastructure, as well as to ethical dilemmas, social stigma, decision-making processes and conflict management.

Since HIV infection is an incurable and life-limiting condition, often associated with low social support, which is treated in a lifelong care process, it is necessary to consider the singularities and specificities of the way these people live, to take care of situations, and to understand their chronic condition, since they will certainly be able to age with the virus, vulnerable to the progression and progression of the disease in its phases, requiring palliative care for the relief of suffering. Thus, the study is not exhaustive, as is the case for the needs of new investigations.

\section{FUNDING}

This study was carried out with the support of the Coordenação de Aperfeiçoamento de Pessoal de Nível Superior- Brazil (CAPES) - Financing Code 001.

\section{REFERENCES}

1. Pio DMP, Reinato LAF, Lopes LP, Gir E. Staphylococcus aureus and the oxacillin sensitivity profile in hospitalized people with HIV/AIDS. Rev Esc Enferm USP [Internet]. 2016 [cited 2016 Nov 15];50(4):614-8. Available from: http://www.scielo.br/pdf/reeusp/v50n4/0080-6234reeusp-50-04-0617.pdf

2. Clark K, Curry T, Byfieldt N. The effect of a care bundle on nursing staff when caring for the dying. Int J Palliat Nurs. 2015;21 (8):392-8. doi: 10.12968/ijpn.2015.21.8.392

3. Biello KB, Oldenburg CE, Safren SA, Rosenberger JG, Novak DS, Mayer KH, et al. Multiple syndemic psychosocial factors are associated with reduced engagement in hiv care among a multinational, online sample of HIV-infected MSM in Latin America. AIDS Care [Internet]. 2016 [cited 2016 Dec 10];28(sup1):84-91. Available from: https://www.ncbi.nlm.nih.gov/pmc/articles/PMC4828614/

4. Souza PN, Miranda EJP, Cruz R, Forte DN. Palliative care for patients with HIV/AIDS admitted to intensive care units. Rev Bras Te. Intensiva[Internet]. 2016 [cited 2016 Dec 10];28(3):301-9. Available from: http://www.scielo.br/pdf/rbti/v28n3/en_0103-507Xrbti-28-03-0301.pdf

5. Al-Dakkak I, Patel S, McCann E, Gadkari A, Prajapati G, Maiese EM. The impact of specific HIV treatment-related adverse events on adherence to antiretroviral therapy: a systematic review and meta-analysis. AIDS Care [Internet]. 2013 [cited 2016 Oct 20];25(4):400-14. Available from: https://www.ncbi.nlm.nih.gov/pmc/articles/PMC3613968/

6. World Health Organization-WHO. Palliative care for people living with HIV: clinical protocol for the WHO European Region[Internet]. 2012 [cited 2016 Aug 25]. Available from: http://www.euro.who.int/en/health-topics/communicable-diseases/hivaids/publications/2012/ hivaids-treatment-and-care.-clinical-protocols-for-the-who-european-region.-2012-revisions

7. Costa TL, Oliveira DC, Formozo GA. Quality of life and AIDS from the perspective of persons living with HIV: a preliminary contribution by the structural approach to social representations. Cad Saúde Pública [Internet]. 2015 [cited 2016 Aug 25];31(2):365-76. Available from: http://www.scielo.br/pdf/csp/v31n2/0102-311X-csp-31-02-00365.pdf

8. Lowther K, Harding R, Ahmed A, Gikaara N, Ali Z, Kariuki H, et al. Conducting experimental research in marginalised populations: clinical and methodological implications from a mixed-methods randomised controlled trial in Kenya. AIDS Care [Internet]. 2016 [cited 2016 Sep 12];28(sup1):60-3. Available from: https://www.ncbi.nIm.nih.gov/pmc/articles/PMC4828598/

9. Adams C, Zacharia S, Masters L, Coffey C, Catalan P. Mental health problems in people living with HIV: changes in the last two decades: the London experience 1990-2014. AIDS Care [Internet]. 2016 [cited 2016 Sep 12];28(sup1):56-9. Available from: https://www.ncbi.nlm.nih.gov/ pmc/articles/PMC4828597/

10. Duarte MTC, Parada CMGL, Souza LR. Vulnerability of women living with HIV/aids. Rev Latino-Am Enfermagem [Internet]. 2014 [cited 2016 Aug 14];22(1):68-75. Available from: http://www.scielo.br/pdf/rlae/v22n1/0104-1169-rlae-22-01-00068.pdf

11. Vasconcelos MF, Costa SFG, Lopes MEL, Abrão FMS, Batista PSS, Oliveira RC. Palliative care for HIV/AIDS patients: bioethical principles adopted by nurses. Cien Saude Colet [Internet]. 2013 [cited 2016 Jan 22];18(9):2559-66. Available from: http://www.scielo.br/pdf/csc/v18n9/ v18n9a10.pdf 
12. Dantas CC, Leite JL, Lima SBS, Stipp MAC. Grounded theory - conceptual and operational aspects: a method possible to be applied in nursing research. Rev Latino-Am Enfermagem [Internet]. 2009 [cited 2015 Nov 10];17(4):573-9. Available from: http://www.scielo.br/pdf/ rlae/v17n4/21.pdf

13. Harries AD, Kumar AM, Karpati A, Jahn A, Douglas GP, Gadabu OJ, et al. Monitoring treatment outcomes in patients with chronic disease: lessons from tuberculosis and HIV/AIDS care and treatment programmes. Trop Med Int Health [Internet]. 2015 [cited 2016 Aug 10];20(7):961-4. Available from: http://onlinelibrary.wiley.com/doi/10.1111/tmi.12506/pdf

14. Silva JB, Cardoso GCP, Netto AR, Kritski AL. The meanings of comorbidity for patients living with TB / HIV: implications in the treatment. Physis [Internet]. 2015 [cited 2016 Aug 10];25(1):209-29. Available from: http://www.scielo.br/pdf/physis/v25n1/0103-7331physis-25-01-00209.pdf

15. Soares VYR, Lúcio Filho CEP, Carvalho LIM, Silva AMMM, Eulálio KD. Clinical and epidemiological analysis of patients with HIV/AIDS admitted to a reference hospital in the northeast region of Brazil. Rev Inst Med Trop[Internet]. 2008 [cited 2015 Jun 10];13(1):419-31. Available from: http://www.scielo.br/pdf/rimtsp/v50n6/v50n6a03.pdf

16. Sehnem GD, Favero NB, Bonadiman POB. Adolescent living with HIV/AIDS: the social support networks. Rev Enferm UFSM. [Internet]. 2015 [cited 2016 Jun 10];5(2):349-59. Available from: https://periodicos.ufsm.br/reufsm/article/view/14996/pdf

17. Huang YT. Challenges and responses in providing palliative care for people living with HIV/AIDS. Int J Palliat Nurs 2013;19(5):218,220-5. doi: 10.12968/ijpn.2013.19.5.218

18. Cunha GH, Galvão MTG, Pibheiro PNC, Vieira NFC. Health literacy for people living with HIV/Aids: an integrative review. Rev Bras Enferm [Internet]. 2017 [cited 2017 May 20];70(1):180-8. Available from: http://www.scielo.br/pdf/reben/v70n1/0034-7167-reben-70-01-0180.pdf

19. Mburu G, Oxenham D, Hodgson I, Nakiyemba A, Seeley J, Bermejo A. Community systems strengthening for HIV Care: experiences from Uganda. J Soc Work End Life Palliat Care [Internet]. 2013 [cited 2016 Jul 10];9(4):343-68. Available from: https://www.ncbi.nlm.nih.gov/pmc/ articles/PMC3869080/

20. Swerissen H, Duckett S. Dying Well. (Report No. 2014-10). Location: The Gratten Institute [Internet]. 2014[cited 2016 Sep 25]. Available from: http://grattan.edu.au/wp-content/uploads/2014/09/815-dying-well.pdf

21. Jacob ER, McKenna L, D’Amore A. The changing skill mix in nursing: considerations for and against different levels of nurse. J Nurs Manag. 2015;23(4):421-6. doi: 10.1111/jonm.12162

22. Jox RJ, Schaider A, Marckmann G, Borasio GD. Medical futility at the end of life: the perspectives of intensive care and palliative care clinicians. J Med Ethics. 2012;38(9):540-5. doi: 10.1136/medethics-2011-100479

23. Alves JAC, Ribeiro C, Campos S. A inteligência emocional em enfermeiros responsáveis por serviços hospitalares. Rev Enfer, Ref [Internet]. 2012 [cited 2016 Jul 25];III(7):33-42. Available from: http://www.scielo.mec.pt/pdf/ref/vserllln7/serllln7a04.pdf

24. Torres E, Christovam BP, Fuly PCS, Silvino ZR, Andrade M. Systematization of nursing assistance as a care management tool: case study. Esc Anna Nery [Internet]. 2011 [cited 2016 Jul 10];15(4):730-6. Available from: http://www.scielo.br/pdf/ean/v15n4/a11v15n4.pdf 